\title{
Diaspora Philanthropy in the Context of Policy Coherence for Development: Implications for the post-2015 Sustainable Development Agenda
}

\author{
Harlan Koff*
}

\begin{abstract}
Thus far, there has been a dearth of studies that systemically examine the relationship between diaspora philanthropy, the development community and securitised migration regimes. This article addresses this by responding to the research question, "How coherent are securitised migration policies with diaspora philanthropy and the transformative development objectives that characterise the Sustainable Development Goals (SDGs) agenda?" The analysis is based on the concept of policy coherence for development (PCD). The article compares the simultaneous regionalization and securitization of European Union and United States migration policies and contends that these policy strategies undermine diaspora philanthropy, development partnerships and transformative development. Normative change must be introduced in order to establish coherence between globalized migration policies and diaspora philanthropy objectives. Normative coherence for development can be achieved by introducing principles from the SDG's and the Busan Development Partnership Agreement amongst other international development agendas, into migration policy-making at the national and regional levels.
\end{abstract}

\section{INTRODUCTION}

The year 2015 was characterized by an important paradox in relation to development and migration. On one hand, the Sustainable Development Goals (SDGs) announced in September of that year were supposed to change the indicator-based Millennium Development Goals (MDG) into a more transformative development programme, including human rights. Conversely, the high profile crises related to unauthorized sea-based migration in the Mediterranean Basin and the terrorist attacks of 13 November in Paris provided explosive fodder for political discourse painting asylum seekers as security threats. These contrasts highlight the character of debates on migration and development: migrants are simultaneously viewed as risks and resources. Consequently, the relationship between migration and development remains ambiguous.

Even though the nature of the relationship between migration and development remains unclear, migrants have historically contributed to development as actors. This has been widely recognized by international organizations and financial institutions which have focused numerous initiatives on migrant remittances. Officially recorded money transfers to the developing world totalled US\$440 billion in 2015, representing $75 \%$ of all remittances worldwide (http://www.worldbank.org/en/

\footnotetext{
* University of Luxembourg
} 
news/press-release/2015/04/13/remittances-growth-to-slow-sharply-in-2015-as-europe-and-russia-stayweak-pick-up-expected-next-year). A major question at the heart of these programmes asks: how can migrants be better integrated into development strategies?

The notion of diaspora philanthropy, broadly defined as a diaspora's transfer of resources to its country of origin in the framework of transnational philanthropy, has evolved within this context. The emerging literature on diaspora philanthropy generally examines the actions of the migrants or the policies of their home states in relation to diaspora philanthropy. Thus far, there has been a dearth of studies that examine the relationship between diaspora philanthropy, the development community and the global migration regime. This article addresses this issue by asking, "How coherent are global migration policies with diaspora philanthropy and transformative development objectives?" The analysis presented below is based on the conceptual approach of policy coherence for development (PCD). PCD is an important policy tool and normative framework that has been championed by the EU and the Organization for Economic Co-operation and Development (OECD) since the 1990s. It proposes policy-making mechanisms aimed at preventing policies in non-development arenas from undermining development strategies. This article examines the recent securitization of migration policies and how it has affected development cooperation.

The article is divided into four parts. Following this introduction, part two presents the literature on diaspora philanthropy within the framework of broader discussions on migration, development and security and it introduces the concept of policy coherence for development. Part three then empirically examines the emergence of diaspora philanthropy strategies within the context of the securitization of development cooperation. Finally, part four presents conclusions.

\section{Research design and methods}

This article examines diaspora philanthropy within the framework of securitized development cooperation in the EU and the US. The cases are comparable because both polities are regional hegemons in terms of migration and security and both are important development aid donors. Conversely, the polities have demonstrated different levels of commitment to PCD as the EU has institutionalized PCD whereas the US has not. In terms of methods, the article is based on a review of secondary literature; EU, OECD, United Nations (UN), World Bank, International Organization for Migration (IOM) and Global Forum on Migration and Development (GFMD) policy documents, as well as reports from non-governmental organizations.

\section{DIASPORA PHILANTHROPY, DEVELOPMENT AND SECURITY: WHAT ROLE FOR PCD?}

The literature on diaspora philanthropy has emerged significantly in recent years. Newland, Tarrazas and Munster (2010) attribute this to three factors: 1) new development actors, 2) new trends in global philanthropy and 3) new trends in diaspora engagement. In general, the literature on this subject has focused on three different approaches. The first relates to the definition and operationalization of diaspora philanthropy. According to Johnson, diaspora philanthropy is the transfer of resources back to home countries "as investments for the social good". (Johnson, 2007). While this conceptualization is relatively straightforward, the operationalization of diaspora philanthropy has been more problematic.

The literature on diaspora philanthropy recognises the heterogeneity of practices in this field. This is especially significant for the literature on diaspora and conflict. Laakso and Hautaniemi (2014) show how diasporas can both contribute to the perpetuation of conflict and foster peace and reconciliation processes. Of course, the mechanisms for conflict resolution or prolongation relate to 
the resources that diasporas mobilise. Do they fund politicized movements? Are initiatives groupspecific or generalised (which is especially relevant for ethnically divided societies)?

Another relevant question asks: What relationships exist between diaspora philanthropy and development aid?. In general, diaspora initiatives can complement, substitute or even undermine development policies (Laakso and Hautaniemi, 2014). This variety of policy impacts is caused by the myriad of ways through which diaspora philanthropy is conducted. Newland, Terraza and Munster (2010) recognize that diaspora philanthropy can be carried out by localized, low-income migrant communities through "hometown associations" or very wealthy migrants who have the means to generalize the impacts of their giving. Also, many organizations donate directly to specific initiatives whereas other migrants give indirectly through intermediaries and foundations (even through the internet).

This heterogeneity in the field of diaspora philanthropy has led to the second group of studies which empirically examines specific practices in different countries. The migrant groups which are most engaged in diaspora philanthropy come from Philippines, India, China, and Mexico. Geithener, Chen and Johnson (2005) comparatively analysed the impacts of diaspora philanthropy initiatives conducted by high-skilled Chinese and Indian migrants aimed at equitable development in these two highly unequal economies. Orozco and Rouse (2007) studied the local impacts of hometown associations in Mexico. Espinosa (2015) examined projects initiated by Filipinos working in the domestic sector. Other scholars have documented diaspora philanthropy in diverse contexts such as Colombia (Aysa-Lastra, 2007), Ghana (Ong'ayo, 2014) and Egypt (Brinkerhoff, 2008).

The third group of studies in the literature on diaspora philanthropy focuses on policy contexts surrounding this phenomenon. These studies have largely been promoted by international organizations such as the IOM, World Bank, etc. or think tanks such as the Migration Policy Institute. The most complete academic work in this sub-field has been published by Brinkerhoff (2012). This article theorizes the relationship between diasporas and their homeland governments, proposes a framework through which homeland governments can enable diasporas' development contributions and identifies mechanisms for the operationalization of this framework. Other works in this field specifically discuss implementation mechanisms. For example, Kleist and Vammen (2012) contend that development policies conducted in association with diaspora philanthropy should be implemented through a participatory approach in which diasporas are consulted on the formulation of migration and development policy objectives.

\section{Migration, Development and Security: What Role for PCD?}

Diaspora philanthropy is not only an academic paradigm or a policy tool, it is also a normative phenomenon because it embraces the notion of globalized citizenship. For this reason, this article contends that diaspora philanthropy must be discussed within the context of the "migrationdevelopment-security nexus." Because diaspora philanthropy recognizes globalized citizenship, it is highly relevant to migration-development-security debates that reinforce nation-state sovereignty.

The literature on migration, development and security has evolved significantly since the 1990s. The literature on the "security-migration nexus" has focused on national security issues. Adamson (2006) claimed that migration was viewed as a threat to national security in terms of shifting 1) state capacity and autonomy, 2) balance of power and 3) the nature of conflict. As the nature of conflict became more decentralized and as non-state security threats emerged further, migration has been viewed as a symbol of both the erosion of state power (Rudolph, 2003) and the international conceptualization of "security" that has become nebulous due to the emergence of new threats and definitions.

These themes have also emerged in the more specific literature on border/migration controls. Authors such as Peter Andreas (2012) have focused their analyses on mechanisms that have 
developed between the securitization of migration and the emergence of a border control industry that has militarized border regions in advanced industrial states. This literature examines the relationship between public perceptions of borders as dangerous areas, the resulting militarization of these borders and the subsequent increase in transnational smuggling and trafficking. Carling (2007), amongst others, has written about the human consequences of these processes.

It is within this framework that the "migration-development" literature has emerged but surprisingly, it has been characterized by a significant cleavage. On one hand, observers have noted that migration has played a significant role in the securitization of development cooperation. Scholars such as Than-Dam Truong and Des Gasper (2011) have identified state concerns about migration as a key mechanism for the securitization of development aid amongst donors such as the European Union and the United States. They discuss four policy concerns which have facilitated securitization of development aid. These are: 1) post-conflict reconstruction and durable solutions for refugees, 2) control over movements facilitated by privately organized networks that undermine state surveillance and challenge state sovereignty, 3) the perceived costs and benefits of migration to hosts and sending states and the lack of sustainable co-development strategies; 4) globalization, the expansion of the knowledge society and governance of the supply of talents.

Conversely, another literature on migration and development has analysed emerging partnerships in the field. This literature has become both extensive and opaque in response to the question: does migration support or undermine development? Some authors, such as Adams, Jr. and Page (2003) contend that migration is a vital resource in the global fight against poverty because they recognize migrants as development actors. Other scholars have contended that migration and remittances have had limited impacts because of unattractive investment environments in sending states (de Haas, 2005) and structural imbalances that exist in global markets (Castle and Delgado Wise, 2007).

This article contends that these debates are limited in their focus. Because they question whether migration facilitates or hinders development and how migrants contribute to development, they fail to recognize an important normative aspect of the migration-development-security nexus that asks: what kind of development should be pursued by migrants and nation-states alike?

It is within this normative framework that policy coherence for development is relevant to discussions on diaspora philanthropy. PCD has emerged as an important policy tool since the 1990s. The EU adopted PCD with the Maastricht Treaty in 1993 and the Cotonou Partnership Agreement in 2000 (Laakso et al., 2007). However, only in 2005 was PCD established on the EU agenda with the Commission adopting a communication with a focus on PCD and the EU Council adopting conclusions on PCD (CEPS, 2006). PCD was also integrated into the EU development policy programme, (European Consensus on Development, EU 2006). The Lisbon Treaty of 2009 further reinforced the European Union commitment to PCD, stating that "the Union shall take account of development cooperation in policies that it implements which are likely to affect developing countries" (Art. 208). The EU is also committed to a biannual PCD reporting process (European Commission, 2007, 2011). In 2007, the decision was made to focus on five priority areas: trade and finance, climate change, global food security, migration, and security. In 2010, the European Commission presented the Policy Coherence for Development Work Programme (EC, 2010) for the years 2010-2013, structured around these five priority areas.

PCD has become so prominent in European politics that it now represents a political statement in global affairs. No longer simply a technical tool, PCD holds a normative value because it prioritizes human development over competing policy arenas. In principle, it can be justified with different arguments. First, PCD aims to ensure that developing countries' current or future prospects are not hurt by industrialized countries' policies (Chang, 2003). Second, PCD highlights the transformative nature of the SDG agenda and is an important policy statement in support of more equitable development.

Thus far, the literature on PCD and migration has focused too specifically on remittances and economic impacts. Dayton-Johnson and Katseli (2006), for example analyse OECD development 
policies through the lens of "flows." Specifically, they discuss aid flows, migration flows, foreign direct investment (FDI) and trade flows. The report coins the term "coherence orphans" to describe a situation in which poor countries receive aid without any of the other flows that are needed to complement it. For these authors, PCD is defined as complementarity of flows which suggests the need to manage circulation rather than control flows at borders. The 2005 study completed by Xenogiani also examined PCD and trade, foreign direct investment and migration with a focus on how migration policies could complement policy-making in these arenas.

Nyberg-Sorensen et al. (2002) took a broader approach to the issue of PCD and migration by investigating the coherence between "relief, recovery, development and conflict prevention". This study goes beyond the traditional economic realm and incorporates a vision of development based on political stability. In the literature on development, scholars acknowledge that the line between humanitarian aid and development cooperation is often blurred. The authors ask: How can both humanitarian aid and development strategies be supported by migration policies? The recommendation of this study is that development aid is more effective than humanitarian assistance because of the active participation of migrants in this process. The most recent work by Nyberg-Sorensen (2016) reflects on the aforementioned study and its impact on Danish development cooperation. According to the author, the goal of coherence between migration policies and development may have been "unrealistic" (Nyberg-Sorensen, 2016: p. 62).

It is within this framework that the issue of normative PCD is relevant to the field of diaspora philanthropy. As stated above, the diaspora philanthropy literature focuses heavily on the activities of migrants and the policies of their home countries. This article contends that this context needs to be expanded. How can we discuss diaspora philanthropy without addressing its coherence with the international migration regime? The securitization of both migration and development through policy strategies aimed at reinforcing the sovereignty of nation-states seems incompatible with diaspora philanthropy initiatives based on global citizenship and transnationalism. For this reason, this article discusses emerging diaspora philanthropy practices in relation to regionalized security agendas through the lens of policy coherence for development.

\section{POLICY COHERENCE FOR DEVELOPMENT AND DIASPORA PHILANTHROPY}

As stated above, diaspora philanthropy has become popular in both the migration and development communities. The United Nations Development Programme (UNDP), amongst other organizations, has noted that resourcing development is one of the most important aspects of the SDG agenda. Even though official development aid (ODA) continues to grow, reaching US\$ 134.8 billion in 2013 (Grady, 2014), its proportion to the total financial flows from OECD member states to the developing world is declining.

Diaspora philanthropy has, in fact, been viewed by many donor states as a "gap-filler" during this time of financial constraint. The Outcome Document from the UN's Third Financing for Development Conference held in Addis Ababa, Ethiopia from 13-16 July, 2015 (United Nations, 2015a) identifies the need to facilitate migrant remittances and other money transfers as a key priority for the global development financing agenda. However, international organizations view much stronger potential in diaspora philanthropy. The International Organization for Migration (IOM) and the Joint Migration and Development Initiative (JMDI) have included diaspora engagement amongst their priorities. In 2013, the IOM reshaped its International Dialogue on Migration into "The Diaspora Ministerial Conference on Diasporas and Development: Bridging Societies and States". This meeting provided a forum in which global leaders could share experiences related to diaspora and development. The agenda reinforced IOM's "3E" (engage, enable and empower) approach to facilitating diaspora participation in development cooperation. The meeting specifically 
addressed the issues of diaspora resources, strategic partnerships and the potential positive impacts of diasporas on crisis situations.

Similarly the JMDI, in which the IOM is a participant as well, has promoted diaspora participation in development cooperation. The JMDI stresses the "local to local" dimensions of migration and development. It promotes strategic partnerships between local governments and civil society that address local needs. Within this framework, it emphasizes the importance of diaspora philanthropy for the links that it promotes between local authorities in home and host countries and the connections that it establishes between local governments and non-governmental organizations (NGOs). It is important to note that the EU is one of the main funders of this initiative.

These themes have also figured prominently in the Global Forum on Migration and Development (GFMD). This forum presents a platform for policymakers and representatives of NGOs to informally exchange views on migration and development issues. Diaspora philanthropy has featured prominently in the yearly GFMD meetings. The ongoing discussions led to the publication of a handbook for policymakers and practitioners entitled Developing a Roadmap for Engaging Diasporas in Development. The purpose of these discussions and the resulting handbook is the establishment of effective strategic development partnerships around diaspora philanthropy.

Finally, it is noteworthy that the World Bank's recognition of diaspora philanthropy has also increased in recent years, albeit from a more technical point of view. Under the broader heading of "diaspora engagement", the World Bank has proposed a set of financial tools through which diaspora philanthropy can be promoted and further linked to development cooperation. These include: 1) mobilization of diaspora savings through diaspora bonds, 2) promotion of a risk-based approach to anti-money laundering and countering the financing of terror (AML/CFT) in order to reduce remittance fees and 3) diaspora transfers as collateral for international borrowing (World Bank, 2015). Thus, the World Bank, like the IOM, the GFMD and the JMDI, recognizes the potential for diaspora philanthropy as an important form of development cooperation. However, these initiatives have been promoted in a vacuum without contextualization in the securitized political environment that currently encompasses global migration debates. This is discussed below.

\section{PCD as a Policy Tool versus PCD as a Normative Statement}

The previous section has outlined the international recognition of diaspora philanthropy in development discussions and the promotion of this paradigm through policies that focus on migrant communities themselves. This article takes a more critical approach. It inquires whether diaspora philanthropy can be considered effective development cooperation by analysing its coherence within securitized migration debates. The argument presented here states that diaspora philanthropy is not hindered by characteristics of migrant communities but instead, the securitized environment that permeates migration in development cooperation undermines it.

PCD in fact, is not a static concept. Classical analysis of PCD compares a donor's development policies to non-development policy arenas (horizontal incoherence) in order to assure that nondevelopment initiatives are not undermining development cooperation objectives. However, scholars of PCD such as Carbone (2008) have recognized different incoherences in development cooperation. These typologies are illustrated in table one.

Table 1 highlights in italics those incoherences which are discussed in the diaspora philanthropy literature. Even though academic and policy studies of diaspora philanthropy do not mention PCD by name, they do often justify this paradigm by referring to at least one of the concepts in the table. For example, the previously mentioned handbook entitled Developing a Roadmap for Engaging Diasporas in Development which was jointly published by the International Organization for Migration and the Migration Policy Institute (2012) has justified the importance of governmentdiaspora partnerships through analysis of internal coherence (how diasporas can inform 
TABLE 1

\section{TYPOLOGIES OF POLICY INCOHERENCE FOR DEVELOPMENT}

\begin{tabular}{|l|}
\hline Horizontal incoherence \\
Vertical incoherence \\
Inter-donor incoher- \\
ence \\
Internal incoherence \\
Inter-organizational \\
incoherence \\
Multilateral incoher- \\
ence \\
Donor-recipient inco- \\
herence \\
Normative incoher- \\
ence
\end{tabular}

Incoherence between development aid and non-aid policies Incoherence between policies of regional organizations and member states Incoherence between development policies of a region's different member states

Inconsistencies between the objectives and means of a given policy Incoherence between the development policies of a donor country's government and civil society organizations

Incompatibility between the development goals and procedural norms of international organizations such as the EU, OECD, the UN, and the international financial institutions

Incoherence between development strategies in donor states and those in aid receiving states

Incoherence between policy strategies in development and non-development policy arenas and core values of liberal democratic societies

Source: Table compiled by the author

development policy means and objectives), inter-organizational coherence (how diasporas can bridge gaps between governments in home and host countries and NGOs) and donor-recipient coherence (how diasporas can contribute to constructive dialogue between actors in donor and aid recipient countries).

These themes are also present in a seminal article on diaspora philanthropy governance by Jennifer Brinkerhoff (2012). In her study, Brinkerhoff examines diaspora-government relations within the context of enabling environments. The framework that she proposes once again does not mention PCD explicitly but it does refer to some core ideas. Her discussion of "mandating," "facilitating" and "resourcing" directly addresses internal PCD. What Brinkerhoff calls "partnering" and "endorsing" are significant for inter-organizational coherence.

This exercise is not intended to criticize the rich literature on diaspora philanthropy, including the excellent work cited above. However, should diaspora philanthropy be considered a new form of development cooperation, then it needs to be embedded in the international norms that guide the global development agenda, including PCD.

One can view PCD in relation to diaspora philanthropy at three policy levels: 1) coherence within diasporas, 2) partnership coherence between diasporas and the development cooperation community and 3) the normative significance of diaspora philanthropy and its impact on development cooperation and migration. Identification of these three levels is important because it recognizes the different meanings that the actions of diasporas hold in relation to development cooperation strategies and migration management.

Intra-diaspora coherence is mentioned in almost every study of diaspora philanthropy. It addresses the dynamics within diaspora communities and discusses how diasporas can expand and improve their initiatives. For example, the IOM-MPI handbook mentioned above identified numerous tools aimed at improving policy efficiency, such as improving knowledge of diasporas through statistical analysis, public consultation, capacity-building and financial tools.

Inter-organizational coherence refers to the relationship between diasporas and governments. Aspects of this type of coherence are also discussed at length within the literature on diaspora philanthropy with the aim of improving policy effectiveness. The aforementioned IOM-MPI handbook introduces policy tools such as the establishment or adaptation of government institutions for diaspora philanthropy, twinning between municipalities in host and home states through diaspora mediation, integrating diasporas into development policy planning, and monitoring and evaluation of diaspora philanthropy initiatives. 
While these types of PCD are significant and they have been discussed in diaspora philanthropy studies using other language, they still frame coherence as a simple policy tool. Thus far, normative dimensions of PCD have been ignored. The post-2015 sustainable development agenda intends to promote transformative development defined as universal development strategies that promote human rights and social justice at the local level and address power imbalances in the global political arena. The SDGs address development relationships through SDG \#10, that focuses on "the reduction of inequality within and among countries," and SDG \#16 which aims to "to promote peaceful and inclusive societies for sustainable development, provide access to justice for all and build effective, accountable and inclusive institutions at all levels." This article contends that these transformative development goals require normative change in global migration politics. For this reason, normative coherence for development has been highlighted in Table 1 above. This concept was introduced in the literature on PCD by Koff and Maganda (2016) and it is defined in this case as coherence between development and migration policies and core democratic values.

Of course, power relationships dominate global migration discussions and migration policies in host countries remain securitized. This has led to policy convergence amongst advanced industrial states (many of which are development aid donor countries) around four policy mechanisms: 1) adoption of conditionality in development aid which includes measures to supress unauthorized migration, 2) the promotion of multilateral and bilateral agreements for repatriation of "illegal" migrants, 3) the externalization of border and migration controls to neighbouring states through financial transfers and 4) the establishment of migrant processing centres in third countries for the deportation of unauthorized migrants to sending countries. Development aid plays a facilitating role in all four policy mechanisms for migration control.

This point can be exemplified through a comparison of EU and US migration policies in relation to development cooperation. Despite recognition by the development agencies of both polities that migration can positively impact development cooperation, migration policies remain highly securitized and affect regional development strategies. In the Americas, the US has regionalized its security strategies through different initiatives. The Plan Sur (also known as the Merida Initiative) was initially funded from 2007-2010 with US\$ 1.6 billion in order to provide US military technology, intelligence and training to Mexico in the war against transnational organized crime. In 2014, the US contributed US\$ 112 million in technology to Mexico's Southern border control efforts, including biometric kiosks, scanners, X-ray machines, the construction of federal police and customs stations, helicopters, ships, communications and training (Red de documentación de las organizaciones defensoras de migrantes, 2014: p. 62.).

The United States has renewed the Plan Sur with a more regional focus by investing further in Central America and the Caribbean and establishing links with the similar Plan Colombia in South America. This regionalization of homeland security has been complemented by development cooperation through the Mesoamerica Project (known as the Plan Puebla Panama (PPP) until 2009), including US\$ 3.5 billion of funding in:

- Energy Sector Integration

- Transportation Integration

- Telecommunications Integration

- Trade Facilitation

- Sustainable Development

- Human Development

- Tourism

- Disaster Prevention and Mitigation

The Mesoamerica Project is a regional development initiative that includes ten member states (Belize, Colombia, Costa Rica, Dominican Republic, El Salvador, Guatemala, Honduras, México, 
Nicaragua, and Panamá). In addition to the US, funding comes from national governments in the region, the Inter-American Development Bank (IDB), the private sector, the Central American Bank for Economic Integration (BCIE), and the World Bank.

The project represents a regional approach to "development, security and stability." This is evident in its relationship to migration. When Mexican President Peña Nieto announced Mexico's Programma Frontera Sur, the 2014 policy aimed at preventing northward migration from Central America, he did so in the company of then Guatemalan President Otto Pérez Molina stating that border controls should not represent walls but instead they should be part of a "humanitarian vision of development, commerce and close cooperation" (http://www.presidencia.gob.mx/articulos-prensa/ pone-en-marcha-el-presidente-enrique-pena-nieto-el-programmea-frontera-sur/). Consequently, even though migration and security are not explicitly designated as prioritized policy arenas, they are present in the programme's agenda.

Scholars of this initiative, such as Villafuerte Solis and Leyva Solano (2006) have argued that both the Plan Sur and the Mesoamerica Project have securitized non-security policy objectives. In line with these criticisms, numerous anti-PPP social movements were established in Mexico and Central America when the plan was announced to protest the securitization of development and migration (see Collombon, 2008). The appearance of these movements indicates significant civil society dissatisfaction with the Mesoamerica Project within Latin America. One point of contention states that the type of development supported by the programme, which is based on infrastructure megaprojects, poorly addresses the lack of PCD in the field of migration and critics contend that such development will actually contribute to further economic displacement, especially in rural areas (see Furlong and Netzahualcoyotzi, 2012). Consequently, regionalized migration-development-security strategies in the Americas are characterized by various policy incoherences, including horizontal incoherence, inter-organization incoherence, multilateral incoherence and above all, normative incoherence because the goal of these initiatives is security rather than development.

Despite its institutional and legal commitment to PCD, the EU has followed a similar migrationdevelopment policy strategy. Like the United States, the European Union has made the regionalization of security policies a priority in its political agenda. The EU has been able to formalize this strategy through treaties and aid agreements. Since the 2002 Seville Council meeting, the EU has strengthened its efforts to control its external borders, including 1) the harmonization of measures to combat illegal migration, including the creation of a common visa identification system, acceleration of the conclusion of readmission agreements with specific countries identified by the Council and approval for elements of a programme on expulsion and repatriation policies, 2) progressive operationalization of coordinated and integrated administration of external borders and 3) the integration of immigration policy in the relations of the Union with third countries.

Obviously, the last of these characteristics of EU migration strategies is most relevant to discussions of PCD. Migration control was further strengthened by the so-called Hague Programme, announced in November 2004, which established a five-year (2005-2010) multi-annual project in the field of justice and security that set "reinforcement of partnerships with third countries to tackle illegal immigration" as a priority for the Commission. Scholars of EU migration policies (Lavanex, 2006) have documented the externalization of European Union migration controls. Aside from the establishment of FRONTEX, the common European border enforcement agency, the EU has funded technical assistance in third countries and integrated migration into regional security strategies through the "Global Approach to Migration Management" (GAMM).

The institutionalization of the role of migration in the context of development cooperation between Europe and Africa officially occurred through the establishment of the Cotonou Partnership Agreement between the members of the African, Caribbean and Pacific (ACP) states and the European Union and its Member States. Specifically articles 13, 79 and 80 of the Agreement specified the role of migration in development partnerships. In particular Article 13 introduced a readmission clause requiring any ACP State to re-admit "its nationals illegally present on the territory" 
of one of the States party to the agreement as well as migrants from other countries who have transited through its territory. This clause also provided for the negotiation of bilateral agreements amongst parties to the agreement to govern "the specific obligations for the readmission and return" of clandestine migrants (art. 13, para. 5).

This decision-making does not support the idea that the EU is more committed to PCD than the US or other advanced industrial polities For example, scholars have noted that the signing of trade agreements and concessions of economic aid are subject to the application of "best practices" in the field of migration (Miranda et al., 2012). Subsequently, these themes have been developed in the various multilateral initiatives on migration issues involving the EU and its African partners. In 2005, the European Council established the GAMM, prioritizing actions in Africa and the Mediterranean with the main objectives of "reducing illegal migration flows and the loss of human lives and assuring the return of illegal immigrants in safe conditions" (Conseil Européen, 2005: 9). This approach also provided that any partnership between the EU and Africa must systematically include aspects related to the management of legal migration, the fight against illegal migration and, the promotion of the link between migration and development. These objectives have most recently been institutionalized in the West Africa Regional Initiative (2015) signed by the EU with the Economic Community of West African States (ECOWAS), l'Union Economique et Monétaire Ouest. Africaine (UEMOA) and member states. The EU will provide $€ 1.15$ billion of funding for the initiative through 2020 (http://europa.eu/rapid/press-release_IP-15-5309_en.htm).

Within these initiatives, the link between migration and development has specifically been articulated through two sets of measures: 1) the outsourcing of border controls, through the sharing of responsibilities in the fight against illegal immigration with African countries (short-medium term goal), 2) the promotion of co-development, understood as development partnerships with African countries with the aim of restricting incentives for unwanted migration (long-term objective). The first Euro-African Intergovernmental Conference on Migration led to a declaration asserting the need to achieve a concerted management of migration in Africa, through the implementation of development projects. This conference was closely followed by another in Tripoli (November 2006) which resulted in a joint statement discussing "strategies to reduce poverty" and "co-development of African countries" as key points to reduce flows of migrants and refugees. The proposed solutions included the promotion of foreign direct investment, cooperation processes and regional economic integration in Africa through the signing of Economic Partnership Agreements.

Within this framework, the EU has unlocked specific budgets since 2001 to finance projects with the main objective of controlling illegal migration (Commission Européenne, 2010). The EU allocated $€ 40$ million for "migration" under the Ninth European Development Fund (EDF). €10 million has been dedicated to the creation of a migration information management (CIGEM) centre in Mali. This centre was established in 2008 following the signature of a joint declaration on "Migration and Development" between Mali, ECOWAS, France, Spain and the European Commission, on 8 February 2007. Also under the 9th EDF, €5.5 million were granted to Mauritania ( $€ 3$ million) and Senegal ( $€ 2.5$ million) for the establishment of "rapid response mechanisms for the fight against illegal migration to the European Union." (Commission Européenne, 2010)

Consequently, this is the political context in which diaspora philanthropy has emerged in Europe and the Americas. This article contends that the securitization of migration by the US and the EU (amongst other donors) has created a normative framework which is detrimental to diaspora philanthropy initiatives. Almost all of the academic and policy studies on diaspora philanthropy, including the aforementioned IOM-MPI handbook, identify trust between governments, NGOs and migrants as the key building block for successful initiatives. However, this point of view has only been directed at home countries. For example, the IOM-MPI handbook states: "A general lack of trust in the non-profit sector and charitable institutions in countries of diaspora origin may lead migrants to focus their contributions on family members and established institutions." (Agunias and Newland, 2012: p. 201) It is important to ask whether the securitization of development and 
migration by host states does not undermine trust to the same extent if not more. This issue is explored in the conclusion below.

\section{CONCLUSION}

Diaspora Philanthropy has recently been promoted by international organizations because it is a paradigm that fits the moment. In a period of expanding development cooperation objectives combined with significant financial constraints, diaspora philanthropy can potentially help development communities meet many needs by facilitating the infusion of private resources, fostering participative development models, mediating twinning between local actors in host and home countries, and promoting innovative partnerships between governments and NGOs. In short, diaspora philanthropy meets the complex programme needs of the current multilateral architecture of international development cooperation.

This narrative offers hope for future innovative development partnerships related to diaspora philanthropy. Nonetheless, the present article contends that the current political atmosphere surrounding immigration will negatively affect the formulation and implementation of diaspora philanthropy programmes and this needs to be discussed more explicitly in the academic and policy literatures. If "trust" is viewed as the building block of effective development partnerships, then present migration policy positions must be considered incoherent with diaspora philanthropy objectives. Already,

FIGURE 1

REAL GLOBAL GOVERNANCE OF DIASPORA PHILANTHROPY

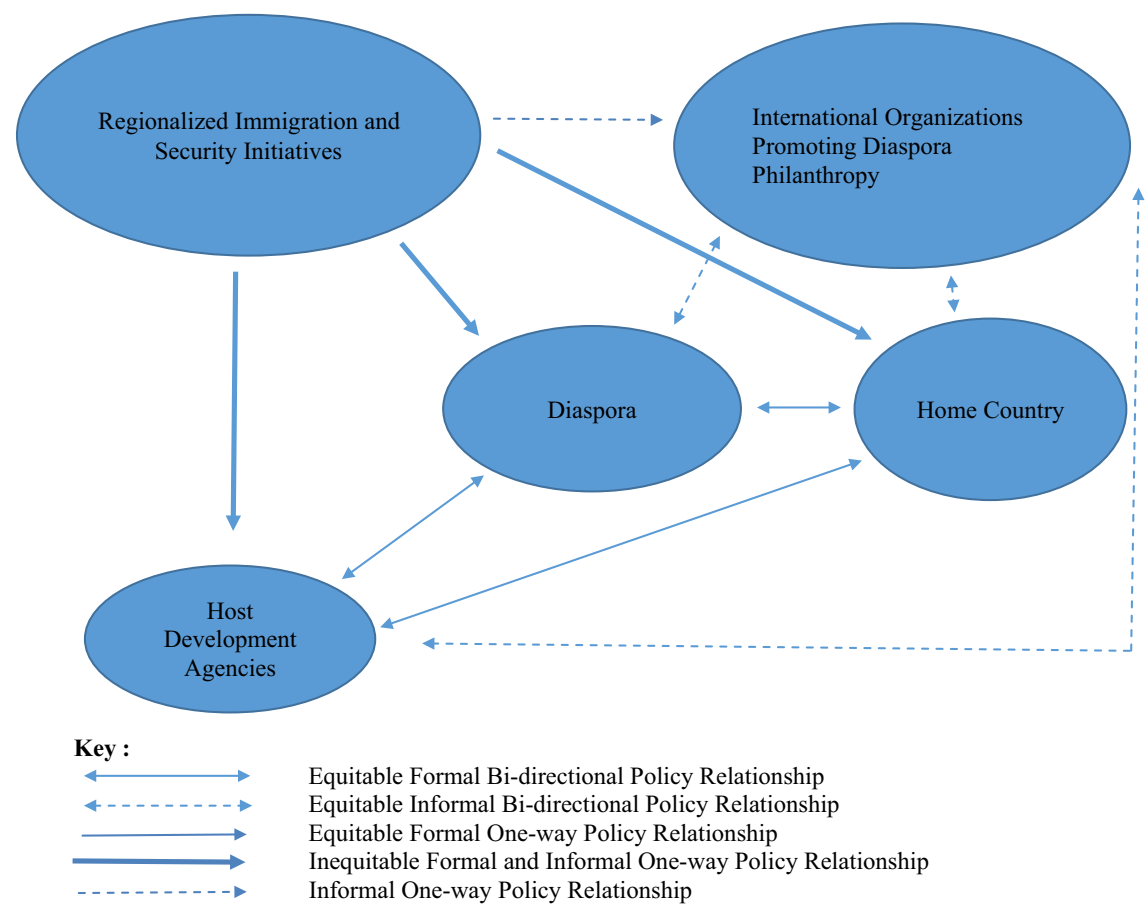

Source: Figure compiled by author. 
the EU has witnessed numerous states (France, Denmark, Hungary, etc.) suspend the Schengen Agreement temporarily in response to Europe's asylum crises.

These nationalist policy positions in the field of migration must be considered incoherent with diaspora philanthropy. One must ask: Why should migrants invest in projects in their home countries in sectors which have been securitized politically through regional development initiatives? At present, the existing relationships between regional security, diaspora philanthropy and development are asymmetrical as shown in Figure 1 and the globalized nature of diaspora philanthropy is incompatible with the overarching debates over state and border sovereignty. Moreover, the regionalization of security through development cooperation also negatively affects transparency and rule of law, which are pillars of diaspora philanthropy because investment depends on their presence. Critics of EU and US migration policies have contended that the regionalization of security initiatives in the Union for the Mediterranean and the Mesoamerica Initiative have negatively impacted transparency and rule of law in border regions in Morocco and Libya on one hand and Mexico on the other, which has led to abuses of the human rights of migrants and citizens alike (see United Nations, 2015b; Cordova and Rodriguez, 2015).

The UNDP has contended that diaspora philanthropy is an innovative paradigm in development cooperation but that it must evolve beyond discussions in once a year summits and be structurally implemented in development cooperation strategies (Grady, 2014). This article contends that international organizations must integrate PCD into their reflections on diaspora philanthropy and development in order for this to occur. Specifically, these organizations should implement mechanisms that target normative coherence for development that matches global migration and development strategies to the core values of the development community as stated in the SDGs and the 2011 Busan Development Agreement. By doing so, the goal of this community should be the

FIGURE 2

HYPOTHETICAL GLOBAL GOVERNANCE OF DIASPORA PHILANTHROPY

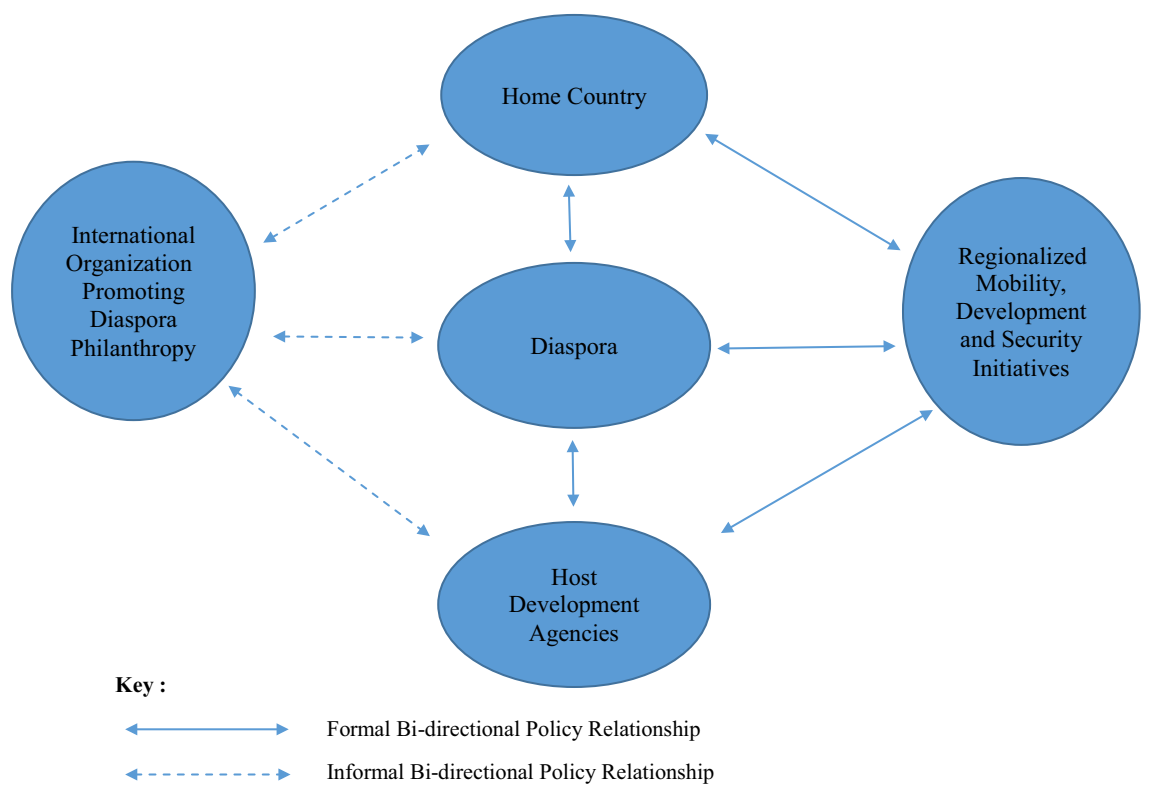

Source: Figure compiled by author. 
establishment of a balanced migration-development regime in which security is pursued in order to promote development (see Figure 2), thus reversing the political relationship which exists today.

Diaspora philanthropy could play a significant role in this process In order for transformative development as expressed in the SDGs to occur, development cooperation and migration management must reflect the globalized community in which we live. At present, securitized migration and development policies aim to reinforce the sovereignty of donors, sometimes at the expense of the sovereignty of aid recipients. Diaspora philanthropy's long-term contribution to development cooperation will hopefully be the infusion of normative coherence for development as diasporas often represent communities of global citizens committed to equitable and transformative global development.

\section{REFERENCES}

Adams Jr, R., and J. Page

2003 "International migration, remittances, and poverty in developing countries." Policy Research Working Paper Series 3179, Washington: The World Bank.

Adamson, F.

2006 "Crossing Borders: International Migration and National Security", International Security, 31(1): $165-199$.

Agunias, D., and K. Newland

2012 Developing a road map for engaging diasporas in development:A handbook for policymakers and practitioners in home and host countries. IOM and Migration Policy Institute, Geneva.

Andreas, Peter

2012 Border Games: Policing the US-Mexico Divide. Cornell University Press, Ithaca, NY.

Aysa-Lastra, M.

2007 Diaspora Philanthropy: The Colombia Experience. The Philanthropic Initiative and The Global Equity Initiative, Boston.

Brinkerhoff, J.

2012 “Creating an Enabling Environment for Diasporas' Participation in Homeland Development", International Migration, 50(1): 75-95.

2008 "Diaspora Philanthropy in an At-risk Society: The Case of Coptic Orphans in Egypt", Non-profit and Voluntary Sector Quarterly, 37: 411-433.

CEPS (Centre for European Policy Studies)

2006 Policy Coherence for Development in the EU Council: Strategies for the Way Forward. Brussels: CEPS.

Carbone, $\mathrm{M}$.

2008 "Mission Impossible: The European Union and Policy Coherence for Development", Journal of European Integration, 30(3): 323-342.

Carling, J.

2007 "Migration Control and Migrant Fatalities at the Spanish-African Borders", International Migration Review, 41(2): 316-343.

Castles, S., and R. Delgado Wise

2008 Migration and Development: Perspectives from the South. IOM, Geneva.

Chang, H.-J.

2003 Kicking Away the Ladder: Development Strategy in Historical Perspective. Anthem Press, London.

Collombon, M.

2008 'Movilizaciones indígenas en contra del Plan Puebla Panamá' In F. Garcia (Ed.) Identidades, etnicidad y racismo en América Latina, FLACSO, Quito: 73-86.

Commission Européenne

2010 "Document de stratégie pour le programme thématique de coopération avec les pays tiers dans le domaine des migrations et de l'asile, UE, 2007-2010". 
Conseil Européen

2005 “Approche globale sur la question des migrations. Priorités d'action centrées sur l'Afrique et la Méditerranée", Union européenne, Bruxelles.

Cordova, R. and H. Rodriguez

2015 "Migración, inseguridad y vulnerabilidad en el corredor del Golfo de México", Regions \& Cohesion, 5(2): 26-49.

Dayton-Johnson, J., and L. Katseli

2006 “Migration, Aid and Trade: Policy Coherence for Development' OECD Development Centre Policy Brief 28. OECD, Paris.

De Haas, H.

2005 "International migration, remittances and development: myths and facts", Third World Quarterly, 26(8): 1269-1284.

Espinosa, S.

2015 "Diaspora Philanthropy: The Making of a New Development Aid", Migration and Development, doi:10.1080/21632324.2015.1053305.

European Commission

2007 "EU Report on Policy Coherence for Development", European Commission, Brussels: COM 545.

2010 "Policy Coherence for Development Work Programme 2010-2013”, European Commission, Brussels: SEC, 2010: 421.

2011 "EU 2011 Report on Policy Coherence for Development” European Commission, Brussels: SEC (2011) 1627.

Furlong, Z.A., and R. Netzahualcoyotzi

2012 "Poverty and Social Exclusion in the Context of the Puebla-Panama Plan" Suma de Negocios 3 (1): 7-19.

Grady, H.

2014 Philanthropy as an Emerging Contributor to Development Cooperation, Brussels, UNDP.

Johnson, P.

2007 Diaspora philanthropy: influences, initiatives, and issues, The Philanthropic Initiative, The Global Equity Initiative. Harvard University, Cambridge, Massachussetts.

Kleist, N., and I. Vammen

2012 "Diaspora Groups and Development in Fragile Situations. Lessons Learnt, Challenges and Dilemmas" DIIS Report 9, DIIS, Copenhagen.

Koff, H. and C. Maganda

2016 "The EU and the Human Right to Water and Sanitation: Normative Coherence as a Key to Transformative Development", European Journal for Development Research, 28(1): 91-110.

Laakso, L., and P. Hautaniemi eds.

2014 Diasporas, Development and Peacemaking in the Horn of Africa, Zed Books, London.

Laakso, L., T. Kivimäki and M. Seppänen

2007 Evaluation of Co-ordination and Coherence in the application of Article 96 of the Cotonou Partnership Agreement. Aksant Academic Publishers, Amsterdam.

Lavenex, S.

2006 "Shifting up and out: The Foreign Policy of European Immigration Control", West European Politics, 29(2): 329-350.

Miranda, V., N. Pirozzi, and K. Schäfer,

2012 "Towards a Stronger Africa-EU Cooperation on Peace and Security: The Role of African Regional Organizations and Civil Society" IAI Working Paper 12/28. Istituto Affari Internazionali, Rome.

Newland, K., A. Terrazas and R. Munster

2010 Diaspora Philanthropy: Private Giving and Public Policy. Migration Policy Institute, Washington, DC.

Nyberg-Sorensen, N.

2016 "Coherence and Contradictions in Danish Migration-Development Policy and Practice", European Journal of Development Research, 28(1): 62-75.

Nyberg-Sorensen, N., N. Van Hear, and P. Engberg-Perdersen

2002 "The Migration-Development Nexus: Evidence and Policy Options' IOM, Geneva. 
Ong'ayo, A.

2014 "How can the EU and Member States Foster Development Through Diaspora Organisations?: The Case of Ghanian Diaspora Organisations in the Netherlands" Discussion Paper 162, ECDPM, Maastricht.

Orozco, M., and R. Rouse

2007 "Migrant Hometown Associations and Opportunites for Development: A Global Perspective." Migration Policy Institute, http://www.migrationpolicy.org/article/migrant-hometown-associationsand-opportunities-development-global-perspective.

Red de documentación de las organizaciones defensoras de migrantes

2014 Migrantes invisibles, violencia tangible: Informe 2014. SJF, Mexico.

Rudolf, C.

2003 "Security and the Political Economy of International Migration", American Political Science Review, 97(4): 603-620.

Truong, T-D., and D. Gasper

2011 "Transnational Migration, Development and Human Security" in T-D. Truong and D. Gasper (Eds.) Transnational Migration and Human Security: The Migration-Development-Security Nexus. Springer, London: $3-22$.

United Nations

2015a "Outcome Document for Third International Conference on Financing for Development" Addis Ababa, 13-16 July 2015, United Nations, New York.

2015b "Report by the Special Rapporteur on the human rights of migrants, François Crépeau. Follow-up mission to Italy (2-6 December 2014)" A/HRC/29/36/Add.2. United Nations General Assembly, New York.

Villafuerte Solis, D., and X. Leyva Solano eds.

2006 Geoeconomía y geopolítica en el área del Plan Puebla Panamá. Camera de Deputados, LVII Legislatura, Mexico.

World Bank.

2015 Migration and Development Brief 24, World Bank, Washington, D.C.

Xenogiani, $\mathrm{T}$.

2005 Policy Coherence for Development: A Background Paper on Migration Policy and its Interactions with Policies on Aid, Trade, and FDI. OECD, Paris. 